\title{
Synthesis and properties of the ivyanes: the parent 1,1-oligocyclopropanes $\dagger$
}

\author{
Gomotsang Bojase, Thanh V. Nguyen, Alan D. Payne, Anthony C. Willis and Michael S. Sherburn*
}

\author{
Received 24th September 2010, Accepted 15th October 2010 \\ DOI: 10.1039/c0sc00500b
}

Practical syntheses of the first six members of the ivyane (1,1-oligocyclopropane) family of fundamental hydrocarbons have been achieved from the cross-conjugated polyenes known as dendralenes. Evidence for helical conformations in both the solid state and in solution is presented. [6]Ivyane exhibits one of the highest experimental heats of combustion recorded for a hydrocarbon. Ring-opening reactions of ivyanes furnish new and interesting structures that are difficult to access by conventional means.

Hydrocarbons continue to provide science with important new theories, structures, reactions and concepts. ${ }^{1}$ Cyclopropanecontaining systems are particularly significant in this regard. ${ }^{2}$ Of the four fundamental hydrocarbon families comprising cyclopropanes (Fig. 1), the "acyclic" 1,1-linked systems are the least well studied.

In fact, of the parent (i.e. unsubstituted) 1,1-linked acyclic oligocyclopropanes, only the tricyclopropane is known. 1,1-Dicyclopropylcyclopropane has been made by several groups ${ }^{3}$ and substituted analogues are also known. ${ }^{4}$ Only one publication, however, describes higher "cyclopropanologues". Thus, in an elegant application of the Matteson homologation, de Mejiere recently reported an iterative approach that produces mixtures of alcohol-substituted 1,1-oligocyclopropanes. ${ }^{5}$ Unfortunately, an attempt to prepare the unsubstituted systems from these substituted analogues was unsuccessful, with ring opened products being formed. ${ }^{5}$ Very recently, we reported short preparative syntheses of the first six members of the dendralene family. ${ }^{6}$ Herein we report the one-step synthesis of the first six members of the unsubstituted 1,1-oligocyclopropanes from the dendralenes. We disclose the physical and chemical properties of these new compounds, which we term the ivyanes, and provide evidence for their helical conformations in both the solid state and in solution.

The dendralenes are the ideal precursors to the ivyanes since, in principle, all that is required is the cyclopropanation of every alkene in the dendralene framework. Encouraged by the reported double cyclopropanation of 1,3-butadiene to bicyclopropyl ${ }^{7}$ and the single cyclopropanation of 1,1-dicyclopropylethylene to [3]ivyane, ${ }^{3 a, b}$ we embarked upon a Simmons-Smith approach. Whereas several different sets of conditions resulted in incomplete conversion and the generation of complex mixtures of products, ${ }^{8}$ Shi's trifluoroacetic acid-activated zinc carbenoid protocol $^{9}$ induced a smooth and complete conversion of the complete series of [3]-[8]dendralenes (Scheme 1).

Research School of Chemistry, Australian National University, Canberra, ACT, 0200, Australia. E-mail: sherburn@rsc.anu.edu.au; Fax: +61-26125-8114

$\dagger$ Electronic supplementary information (ESI) available: Experimental procedures, characterization data of all new compounds, X-ray crystal structures of [7]- and [8]ivyanes and thermal stability/calorimetry studies on [6]ivyane. CCDC reference numbers 766962 ([7]ivyane) and 766963 ([8]ivyane). For ESI and crystallographic data in CIF or other electronic format see DOI: $10.1039 / \mathrm{c} 0 \mathrm{sc} 00500 \mathrm{~b}$

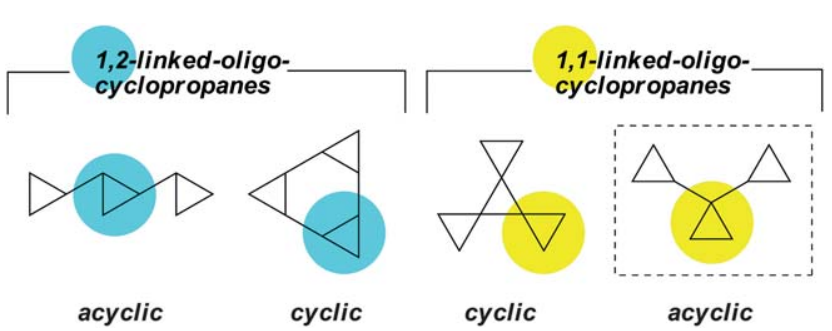

Fig. 1 Selected fundamental hydrocarbon families based upon cyclopropanes. The sub-type under scrutiny is in a dashed box.

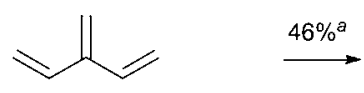

[3]dendralene<smiles>C=CC(=C)C(=C)C=C</smiles>

[4]dendralene<smiles>C=CC(=C)C(=C)C(=C)C=C</smiles>

[5]dendralene<smiles>C=CC(=C)C(=C)C(=C)C(=C)C(C)(C)C</smiles><smiles>C=CC(=C)C(=C)C(=C)C(=C)C(=C)C(=O)OC</smiles><smiles>C=CC(=C)C(=C)C(=C)C(=C)C(=C)C(=C)C=CC(C)(C)Br</smiles>

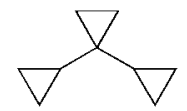

[3]ivyane

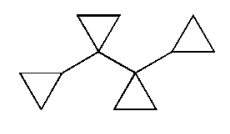

[4]ivyane
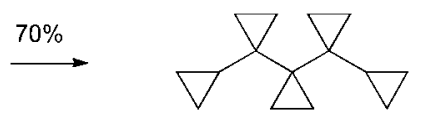

[5]ivyane

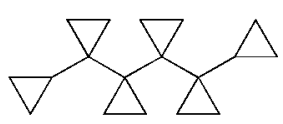

[6]ivyane

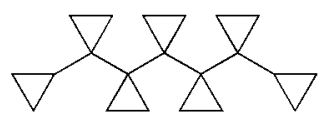

[7]ivyane

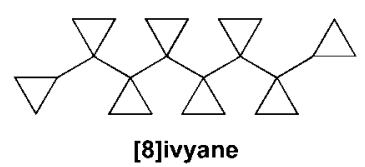

Scheme 1 Practical syntheses of [3] [8]ivyanes through cyclopropanation of the dendralenes. Reagents and conditions: $\mathrm{Et}_{2} \mathrm{Zn}$ (1.2 mol equiv. per alkene), $\mathrm{CF}_{3} \mathrm{CO}_{2} \mathrm{H}$ (1.2 mol equiv. per alkene), hexanes- $\mathrm{CH}_{2} \mathrm{Cl}_{2}, 0{ }^{\circ} \mathrm{C}, 20 \mathrm{~min}$, then $\mathrm{CH}_{2} \mathrm{I}_{2}$ (1.2 mol equiv. per alkene), $20 \mathrm{~min}$, then add dendralene (1 mol equiv.), $0{ }^{\circ} \mathrm{C}$ to rt, $2 \mathrm{~h} .{ }^{a} 1.5$ mol equiv. of reagents per alkene used. ${ }^{b} 18 \mathrm{~h}$ reaction time. 
As demonstrated in the Experimental section, ${ }^{10}$ the procedure lends itself to the gram-scale synthesis of the ivyanes. The efficiency of these reactions is best appreciated by considering the conversion of [8]dendralene into [8]ivyane; the transformation involves the formation of no less than $16 \mathrm{C}-\mathrm{C}$ bonds and affords the product in an isolated yield of $81 \%$. The ivyanes are sensitive towards $\mathrm{Br} ø n s t e d$ acid (a reaction with an acid is discussed later). Interestingly, [3]ivyane appears to be the most acid-sensitive member of the family, and this is reflected in the abnormally low isolated yield of this hydrocarbon following flash column chromatography.

Despite their strain energy (a cyclopropane ring has strain energy of $c a .115 \mathrm{~kJ} \mathrm{~mol}^{-1}$ ), ${ }^{11}$ the ivyanes are kinetically stable to moderate temperatures. [8]Ivyane, for example, melts at $95^{\circ} \mathrm{C}$ in air without significant decomposition and [6]ivyane is kinetically stable to $c a .200{ }^{\circ} \mathrm{C}$, as demonstrated from DSC experiments. ${ }^{10}$ The experimental heat of combustion of [6]ivyane was found to be $50.8 \pm 2.5 \mathrm{MJ} \mathrm{kg}^{-1}(12.3 \pm 0.6 \mathrm{MJ}$ $\left.\mathrm{mol}^{-1}\right){ }^{10}$ which is one of the highest reported for a hydrocarbon, ${ }^{12}$ and is significantly higher than that of cubane..$^{13}$ The molar heat of combustion of [6]ivyane is roughly six times that of cyclopropane $\left(2.1 \mathrm{MJ} \mathrm{mol}^{-1}\right) .{ }^{12}$ Furthermore, the heats of combustion per $\mathrm{kg}$ for these two compounds are very similar (cyclopropane $=49.7 \mathrm{MJ} \mathrm{kg}^{-1}$ ). ${ }^{12}$ Thus, the thermodynamic strain energies in isolated and covalently connected cyclopropane rings are comparable, and the connected nature of the cyclopropane rings in the ivyane structure does not lead to a decrease in kinetic stability.

[3]-[6]Ivyanes are oils at ambient temperature but [7]- and [8]ivyanes are solids. Crystals suitable for single-crystal X-ray analysis were grown from $n$-pentane and the molecular structures of [7]ivyane and [8]ivyane are depicted in Fig. 2.

These first X-ray crystal structures of parent ivyanes (see ESI $\dagger$ ) confirm the B3LYP/6-31G(d) predicted (gas phase) helical conformations and are consistent with X-ray structures of substituted [3]-, [4]- and [5]ivyanes reported by de Meijere. ${ }^{5}$ The gauche conformation between adjacent cyclopropanes means that one turn of the helix involves a five carbon chain. The composition of each crystal studied is racemic, with unit cells containing both enantiomeric structures.

Whereas bicyclopropyl (i.e. [2]ivyane) has long been known to exist as a roughly equimolar mixture of s-trans and gauche conformers in the liquid and gas phase,$^{15}$ to our knowledge, no information relating to solution-phase conformations of ivyanes has been reported. ${ }^{13} \mathrm{C}$ NMR spectra of [6]ivyane recorded at 25 and $-80^{\circ} \mathrm{C}$ are reproduced in Fig. 3. As might be expected from a symmetrical structure, the higher temperature spectrum contains six resonances $\left(2 \times \mathrm{C}, 1 \times \mathrm{CH}, 3 \times \mathrm{CH}_{2}\right)$. Nevertheless, the broad methylene signal at $\delta 8.1 \mathrm{ppm}$ betrays exchange on the NMR timescale.

Indeed, at $-80^{\circ} \mathrm{C}$, nine sharp carbon signals are resolved $(2 \times$ $\mathrm{C}, 1 \times \mathrm{CH}, 6 \times \mathrm{CH}_{2}$ ), a result consistent with the presence of a less symmetrical (i.e. helical) conformation. ${ }^{16}$ Interconversion between the two enantiomeric helical conformations (Scheme 2) results in an interchange of the environment of each cyclopropane's pair of methylenes. At the higher temperature, exchange is sufficiently rapid on the NMR timescale that a single averaged methylene resonance is witnessed for each cyclopropane.
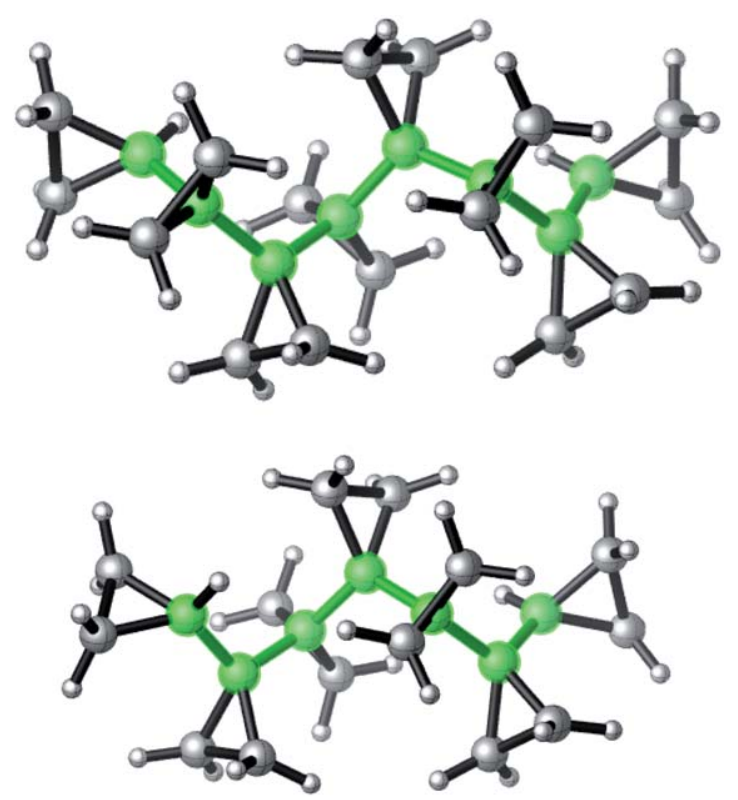

Fig. 2 Molecular structures of ivyanes based upon coordinates obtained from single-crystal X-ray analyses: (top) molecular structure of [8]ivyane; (bottom) molecular structure of [7]ivyane. Helical chains are highlighted green. ${ }^{14}$

The unique nature of the ivyane structure prompts the question of ring-opening transformations, and preliminary investigations towards this end are depicted in Scheme 3. Thus, regioselective hydrogenolysis of [6]ivyane gives the highly

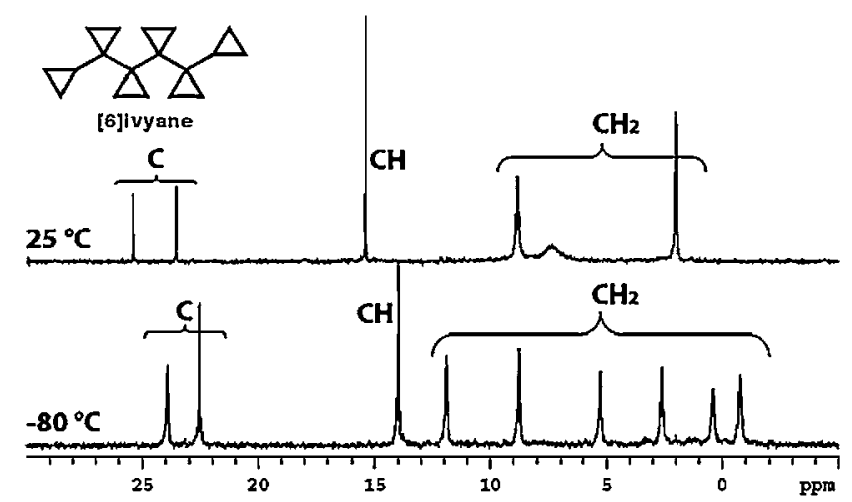

Fig. 3 Broad-band decoupled ${ }^{13} \mathrm{C}$ NMR spectra $\left(125 \mathrm{MHz}, \mathrm{CD}_{2} \mathrm{Cl}_{2}\right)$ of [6]ivyane at +25 and $-80^{\circ} \mathrm{C}$. Assignments from DEPT experiments.

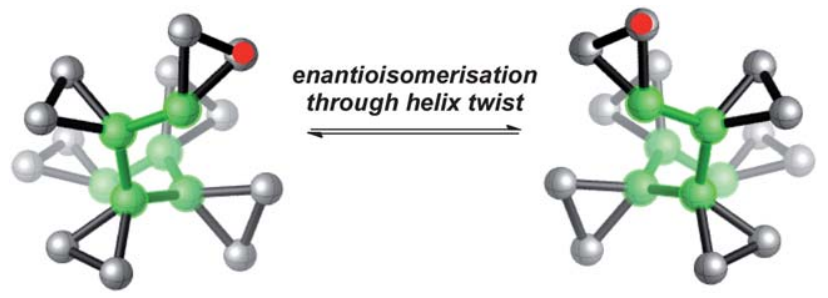

Scheme 2 Enantioisomerisation in ivyanes. Interconversion between the two enantiomers is depicted for [6]ivyane, with the helical, six-carbon chain highlighted in green. $\mathrm{H}$ atoms are omitted for clarity. Note the interchange of environment for each cyclopropane's pair of methylenes $\left(\right.$ red tag). ${ }^{14}$ 


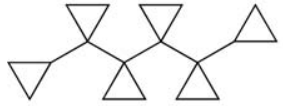

[6]ivyane

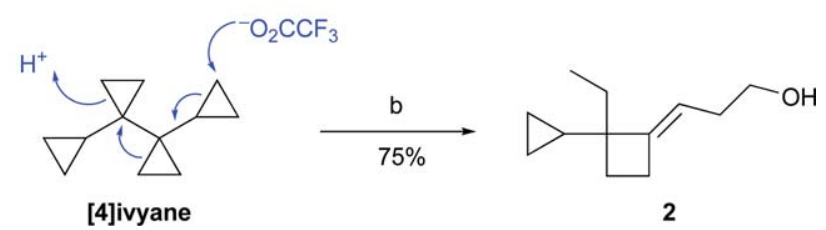

Scheme 3 Ring-opening transformations of ivyanes. Reagents and conditions: (a) $\mathrm{PtO}_{2}\left(0.4\right.$ mol equiv.), $\mathrm{CH}_{3} \mathrm{COOH}, \mathrm{H}_{2}(1.6 \mathrm{~atm}), 40^{\circ} \mathrm{C}, 12 \mathrm{~h}$. (b) (i) $\mathrm{CF}_{3} \mathrm{COOH}$ (6 mol equiv.), $\mathrm{CH}_{2} \mathrm{Cl}_{2}, \mathrm{rt}, 6 \mathrm{~h}$; (ii) $\mathrm{KOH}, \mathrm{MeOH}, \mathrm{rt}, 2 \mathrm{~h}$.

substituted acyclic hydrocarbon 1, bearing four contiguous quaternary centres. Effective routes to such compounds are lacking in the literature. ${ }^{17}$

On the other hand, treatment of [4]ivyane with trifluoroacetic acid furnishes alcohol $\mathbf{2}$ after hydrolysis of the corresponding trifluoroacetate. ${ }^{10}$ This last transformation demonstrates that adjacent cyclopropane rings in the ivyanes can react in a cooperative manner. ${ }^{18}$

\section{Conclusions}

In summary, the 1,1-linked acyclic oligocyclopropane family of fundamental hydrocarbons have been synthesised for the first time. Successful preparations of the first six members of the family involve efficient per-cyclopropanation reactions of the corresponding dendralenes. The ivyanes adopt chiral helical conformations in both solid and solution phases. The simplicity of this synthetic approach should lend itself to the construction of related systems, perhaps including compounds with a barrier towards interconversion that is sufficiently high to allow the isolation of single enantiomeric helices at ambient temperature. Given the importance of helical molecules in nature, ivyanes are clearly worthy of further investigation.

\section{Experimental section}

\section{Representative procedure: synthesis of [6]ivyane}

To a two-neck round bottom flask containing dry dichloromethane $(40 \mathrm{~mL})$ at $0{ }^{\circ} \mathrm{C}$ under a nitrogen atmosphere was added a $1 \mathrm{M}$ solution of diethyl zinc in hexanes $(47.6 \mathrm{~mL}, 47.6 \mathrm{mmol}$ 7.2 mol equiv.). A solution of trifluoroacetic acid $(3.67 \mathrm{~mL}$, $47.6 \mathrm{mmol}, 7.2 \mathrm{~mol}$ equiv.) in dry dichloromethane $(20 \mathrm{~mL})$ was added dropwise and the resulting mixture was vigorously stirred for $20 \mathrm{~min}$. A solution of diiodomethane $(3.83 \mathrm{~mL}, 47.6 \mathrm{mmol}$, $7.2 \mathrm{~mol}$ equiv.) in dichloromethane $(20 \mathrm{~mL})$ was added dropwise and the resulting mixture was vigorously stirred for another $20 \mathrm{~min}$. The reaction mixture was maintained at $0{ }^{\circ} \mathrm{C}$ during this time. A solution of [6]dendralene $(1.04 \mathrm{~g}, 6.6 \mathrm{mmol}, 1.0 \mathrm{~mol}$ equiv.) in dichloromethane $(20 \mathrm{~mL})$ was then added and the reaction mixture was slowly warmed to $\mathrm{rt}$ and stirred for $5 \mathrm{~h}$. The reaction mixture was then quenched with a solution of saturated aqueous $\mathrm{NH}_{4} \mathrm{Cl}(50 \mathrm{~mL})$ and the organic and aqueous layers were separated. The aqueous layer was extracted with more dichloromethane $(2 \times 20 \mathrm{~mL})$ and the combined organic extracts were washed with water, saturated aqueous $\mathrm{NaCl}$ then dried over anhydrous $\mathrm{MgSO}_{4}$ and concentrated in vacuo $\left(20 \mathrm{mbar}, 0{ }^{\circ} \mathrm{C}\right)$ to give an oil. The oil was purified by flash chromatography (40 $\mathrm{g}$ $\mathrm{SiO}_{2}$, pentane) to give [6]ivyane $(1.42 \mathrm{~g}, 89 \%)$ as a colourless oil: $R_{\mathrm{f}} 0.60$ (pentane); $\delta_{\mathrm{H}}\left(500 \mathrm{MHz}, \mathrm{CDCl}_{3}\right): 1.56(2 \mathrm{H}, \mathrm{tt}, J 8.0,6.0)$, 0.33 (4H, m), 0.24 (8H, m), 0.19 (4H, br s), 0.02 (4H, br s), -0.09 $(4 \mathrm{H}, \mathrm{m}) \mathrm{ppm} ; \delta_{\mathrm{C}}\left(125 \mathrm{MHz}, \mathrm{CDCl}_{3}\right): 25.4(2 \times \mathrm{C}), 23.5(2 \times \mathrm{C})$, $15.3(2 \times \mathrm{CH}), 8.9\left(4 \times \mathrm{CH}_{2}\right), 7.4\left(4 \times \mathrm{CH}_{2}\right), 2.1\left(4 \times \mathrm{CH}_{2}\right) \mathrm{ppm}$; $\nu_{\max }\left(\right.$ thin film) $/ \mathrm{cm}^{-1} 3079,3008,1469,1018 ; \mathrm{m} / \mathrm{z}(40 \mathrm{eV}, \mathrm{EI}) 242$ $\left(\mathrm{M}^{+}, 1 \%\right), 214\left(\mathrm{M}^{+}-\mathrm{C}_{2} \mathrm{H}_{4}, 72\right), 185$ (70), 91 (100), 79 (92); HRMS: calc. for $\mathrm{C}_{18} \mathrm{H}_{26}\left(\mathrm{M}^{+}\right)$: 242.2035; found 242.2021.

\section{Acknowledgements}

Funding from the Australian Research Council (ARC) is gratefully acknowledged. We thank A/Prof. Hans Riesen and Dr Barry Gray of the University of New South Wales at the Australian Defence Force Academy, Canberra for assistance in conducting calorimetric analyses.

\section{Notes and references}

1 (a) H. Hopf, in Classics in Hydrocarbon Chemistry: Syntheses, Concepts, Perspectives, Wiley-VCH, Weinheim, 2000; (b) CarbonRich Compounds: From Molecules to Materials, ed. M. M. Haley, R. R. Tykwinski, Wiley-VCH, Weinheim, 2006.

2 (a) A. de Meijere, S. I. Kozhushkov and H. Schill, Chem. Rev., 2006, 106, 4926-4996; (b) A. de Meijere, S. I. Kozhushkov, A. A. Folkin, I. Emme, S. Redlich and P. R. Schreiner, Pure Appl. Chem., 2003, 75, 549-562.

3 (a) F. Effenberger and W. Podszun, Angew. Chem., Int. Ed. Engl., 1969, 8, 976; (b) O. M. Nefedov, I. E. Dolgii, I. B. Shvedova and R. N. Shafran, Bull. Acad. Sci. USSR, Div. Chem. Sci. (Engl. Transl.), 1972, 21, 1834-1836; Izv. Akad. Nauk SSSR Ser. Khim., 1972, 21, 1885-1887; (c) W. Weber, U. Behrens and A. de Meijere, Chem. Ber., 1981, 114, 1196-1199; (d) T. K. Klindukhova, G. N. Suvorova, L. B. Koroleva and M. I. Komendantov, Zh. Org. Khim., 1984, 20, 529-532; J. Org. Chem. USSR (Engl. Transl.), 1984, 20, 477-479.

4 (a) S. Nishida, M. Murakami, T. Mizuno and T. Tsuji, J. Org. Chem., 1989, 54, 3868-3872; (b) N. A. Donskaya, A. G. Bessmertnikh and Y. S. Shabarov, Zh. Org. Khim., 1989, 25, 332-339; J. Org. Chem. USSR (Engl. Transl.), 1989, 25, 295-301; (c) N. S. Zefirov, K. A. Lukin, S. I. Kozhushkov, T. S. Kuznetsova, A. M. Domarev and I. M. Sosonkin, Zh. Org. Khim., 1989, 25, 312-319; J. Org. Chem. USSR (Engl. Transl.), 1989, 25, 278-284; (d) T. Imamoto, Y. Kamiya, T. Hatajima and H. Takahashi, Tetrahedron Lett., 1989, 30, 5149-5152; (e) T. Imamoto, T. Hatajima, N. Takiyama, T. Takeyama, Y. Kamiya and T. Yoshizawa, J. Chem. Soc., Perkin Trans. 1, 1991, 3127-3135; (f) N. A. Donskaya and A. G. Bessmertnykh, Zh. Org. Khim., 1991, 27, 1681-1685; J. Org. Chem. USSR (Engl. Transl.), 1991, 27, 1474-1478; (g) S. Nishida, N. Asanuma, M. Murakami, T. Tsuji and T. Imai, J. Org. Chem., 1992, 57, 4658-4663.

5 T. Kurahashi, S. I. Kozhushkov, H. Schill, K. Meindl, S. Rühl and A. de Meijere, Angew. Chem., Int. Ed., 2007, 46, 6545-6548.

6 A. D. Payne, G. Bojase, M. N. Paddon-Row and M. S. Sherburn, Angew. Chem., Int. Ed., 2009, 48, 4836-4839.

7 (a) M. C. Guerreiro and U. Schuchardt, Synth. Commun., 1996, 26, 1793-1800; (b) G. Wittig and F. Wingler, Chem. Ber., 1964, 97, 2146-2164; (c) C. G. Overberger and G. W. Halek, J. Org. Chem., 1963, 28, 867-868.

8 The original Simmons-Smith procedure $\left(\mathrm{Zn} / \mathrm{Cu}\right.$ couple, $\mathrm{CH}_{2} \mathrm{I}_{2}, \mathrm{Et}_{2} \mathrm{O}$, reflux: H. E. Simmons and R. D. Smith, J. Am. Chem. Soc., 1959, 81, 4256-4264) and variations led to incomplete conversions, as did attempts involving dihalocarbene additions under PTC conditions $\left(\mathrm{CHX}_{3}, \mathrm{Et}_{3} \mathrm{NBnCl}, \mathrm{NaOH}, \mathrm{CH}_{2} \mathrm{Cl}_{2}\right.$ : C. M. Starks, J. Am. Chem. Soc., 1971, 93, 195-199). 
9 Z. Yang, J. C. Lorenz and Y. Shi, Tetrahedron Lett., 1998, 39, 8621-8624.

10 See ESI $\uparrow$ for details.

11 R. D. Bach and O. Dmitrenko, J. Am. Chem. Soc., 2006, 128, 45984611.

12 E. S. Domalski, J. Phys. Chem. Ref. Data, 1972, 1, 221-278; see ESI† for details.

13 The value for cubane is $46.5 \mathrm{MJ} \mathrm{kg}^{-1}$ : P. Eaton, N. Nodari, C. Neri, L. Cassar, F. Monti and F. Alberici, Fuel Composition with a High Energy Content, Eur. Pat., 036 4051, 1990; values for related strained structures are provided in ESI $\uparrow$.

14 Molecule visualisations were created using CYLview, v1.0b; C. Y. Legault, Université de Sherbrooke, 2009. http:// www.cylview.org (accessed Sept. 22, 2010).
15 (a) W. Lüttke, A. de Meijere, H. Wolff, H. Ludwig and H. W. Schrötter, Angew. Chem., Int. Ed. Engl., 1966, 5, 123-124; (b) O. Bastiansen and A. de Meijere, Angew. Chem., Int. Ed. Engl., 1966, 5, 124-125.

16 While the proposed helical conformation in solution is consistent with these VTNMR data, we cannot rule out other conformations at this stage.

17 For a recent method involving a Hg-mediated radical photodimerisation: S. P. Verevkin, M. Nölke, H.-D. Beckhaus and C. Rüchardt, J. Org. Chem., 1997, 62, 4683-4686.

18 This sequence differs from that witnessed in the rotane series, see: L. Fitjer and D. Wehle, Angew. Chem., Int. Ed. Engl., 1979, 18, 868-869. 